\title{
DO PATIENTS WITH SOMATIC ILLNESSES WANT PHYSICIANS TO ADDRESS POSSIBLE SEXUAL DYSFUNCTIONS FOLLOWING THEIR DISEASES?
}

\author{
Donec Venta, Lithuanian University of Health Sciences - Kaunas, Lithuania
}

Introduction: Many somatic diseases may negatively impact sexual health and lead to different dysfunctions and disabilities. This creates the need in the rehabilitation process to address possible sexual problems and provide professional help. However, to address sexual issues well in clinical settings, as a very intimate and sensitive topic, is often complicated by many psychological, social and cultural barriers that exist both in patients, physicians and other rehabilitation specialists.

Purpose: To evaluate patients' attitudes towards physicians' role in dealing with sexual dysfunctions following somatic illnesses.

Methods: Patients with different somatic pathologies filled in the self-administered anonymous survey of sociodemographic questions, questions about their health, sexual functioning and their attitudes to the physician's role in dealing with possible sexual dysfunctions following their pathology. Chosen level of significance was $p<0.05$.

Results: 203 patients participated (average age was 51.2 years \pm 12.7 ). $32 \%$ of them were men. Only $9.9 \%$ of respondents marked that they had experienced their physician initiating a conversation towards sexual dysfunctions following their somatic diseases in their previous care. $32 \%$ indicated preference for the physician's initiative to address possible sexual dysfunctions connected to their diseases; 35,9\% - expressed clear reluctance to such physician's initiative; $26.1 \%$ were not sure about their preferences; $6.4 \%$ - did not respond.

Table 1.

During your appointment would you like your doctor to discuss possible negative effects of your illness on your sexual function?

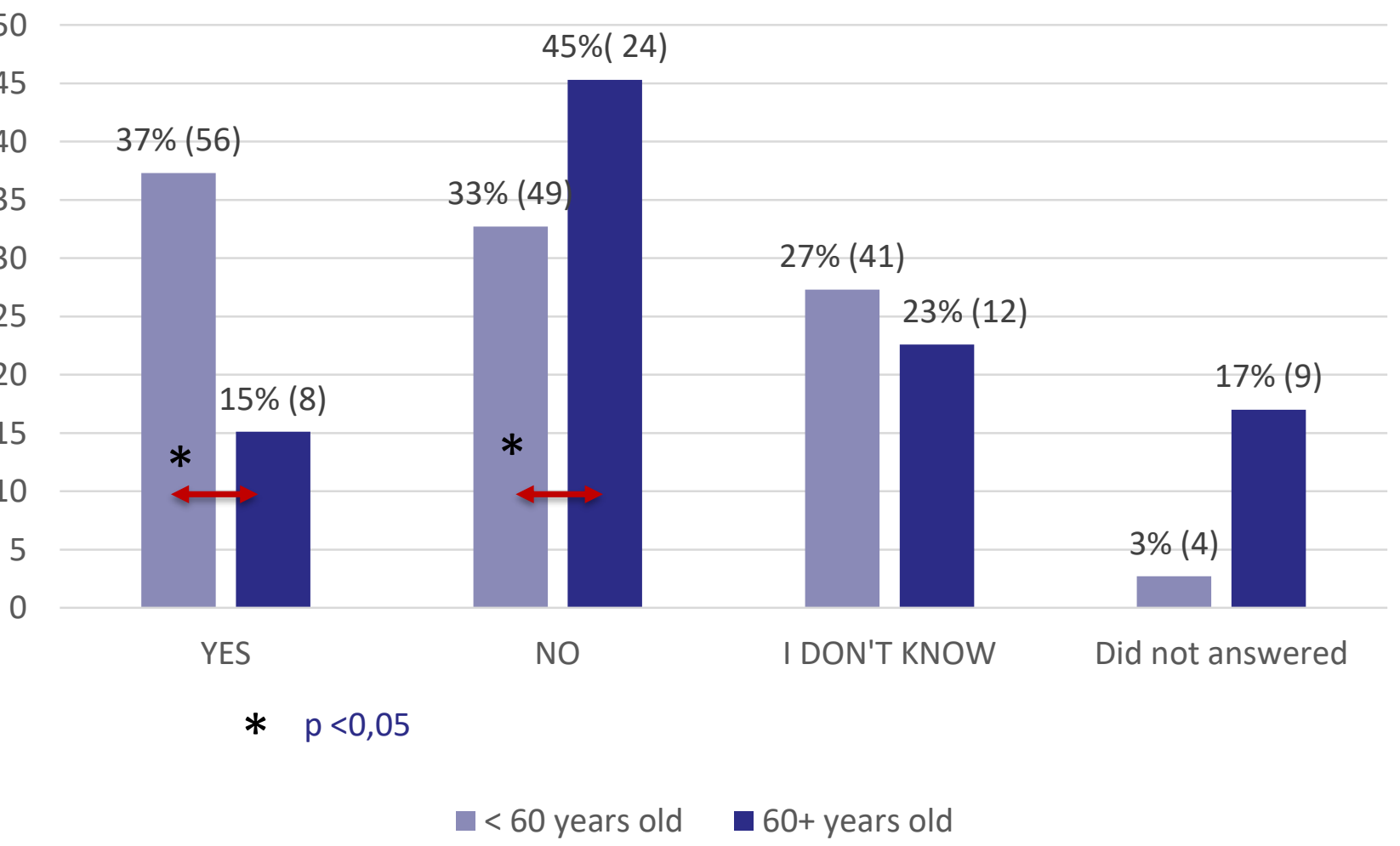

Younger patients (Table 1), those who live in partnerships, had gynecological pathology, less concomitant diseases, showed higher interest in receiving consultation about sexual dysfunctions from physicians $(p<0.05)$ (Table 2). Discussion and Conclusion: Only a minority of patients expressed clear reluctance for a physician's initiative to address possible sexual dysfunctions following their somatic diseases. Our results indicate that physicians' approach was inadequate and possible sexual dysfunctions were not addressed in most cases during former patient care. Further studies researching possible barriers and ways to overcome them, when dealing with sexual dysfunction issues in clinical settings, are needed.

Table 2.

\begin{tabular}{|c|c|c|c|c|}
\hline \multirow{2}{*}{\multicolumn{2}{|c|}{$\begin{array}{l}\text { During your appointment would you like } \\
\text { your doctor to discuss possible negative } \\
\text { effects of your illness on your sexual } \\
\text { function? }\end{array}$}} & \multicolumn{2}{|c|}{ The answer of respondents } & \multirow[t]{2}{*}{$p$ value } \\
\hline & & YES & NO & \\
\hline Education & $\begin{array}{r}\text { Secondary } \\
\text { Post secondary } \\
\text { Higher education }\end{array}$ & $\begin{array}{l}40 \%(19) \\
48 \%(20) \\
54 \%(25)\end{array}$ & $\begin{array}{l}60 \%(29) \\
52 \%(22) \\
46 \%(21)\end{array}$ & 0.36 \\
\hline Sex & $\begin{array}{r}\text { Male } \\
\text { Female }\end{array}$ & $\begin{array}{l}46 \%(19) \\
47 \%(45)\end{array}$ & $\begin{array}{l}54 \%(22) \\
53 \%(51)\end{array}$ & 0.95 \\
\hline Relational status & $\begin{array}{r}\text { Single } \\
\text { In relationship }\end{array}$ & $\begin{array}{l}27 \%(10) \\
54 \%(54)\end{array}$ & $\begin{array}{l}73 \%(27) \\
46 \%(46)\end{array}$ & 0.005 \\
\hline $\begin{array}{l}\text { Stage of present } \\
\text { disease }\end{array}$ & $\begin{array}{r}\text { Acute } \\
\text { Chronic }\end{array}$ & $\begin{array}{l}67 \%(4) \\
45 \%(52)\end{array}$ & $\begin{array}{c}33 \%(2) \\
55 \%(63)\end{array}$ & 0.3 \\
\hline Present disease & $\begin{array}{r}\text { MSC system } \\
\text { Systemic-autoimune } \\
\text { Endocrine } \\
\text { Gynecological } \\
\text { Unspecified vertebral } \\
\text { disorder } \\
\text { Other internal organs } \\
\text { disease }\end{array}$ & $\begin{array}{c}37 \%(14) \\
24 \%(8) \\
53 \%(9) \\
88 \%(28) \\
33 \%(2) \\
50 \%(1)\end{array}$ & $\begin{array}{c}63 \%(24) \\
77 \%(26) \\
47 \%(8) \\
13 \%(4) \\
67 \%(4) \\
50 \%(1)\end{array}$ & $<0.001$ \\
\hline $\begin{array}{l}\text { Number of } \\
\text { concomitant } \\
\text { diseases }\end{array}$ & $\begin{array}{r}1 \\
2 \\
\geq 3\end{array}$ & $\begin{array}{c}53 \%(31) \\
36 \%(8) \\
7 \%(1)\end{array}$ & $\begin{array}{l}47 \%(28) \\
64 \%(14) \\
83 \%(13)\end{array}$ & 0.04 \\
\hline
\end{tabular}

Aknowledgements: the author thanks Vaiva ZadorožnaitèVaičienè, Indrè Mikutaitienè and Dovilè Sungailaitè, for the help in carrying out the research.

\section{References:}

1. Elliott S, Hocaloski S, Carlson M. A Multidisciplinary Approach to Sexual and Fertility Rehabilitation: The Sexual Rehabilitation Framework. Top Spinal Cord Inj Rehabil. 2017 Winter;23(1):49-56

2. Żuk B, Maślińska M. The importance of physiotherapy in the sexuality of patients with rheumatic diseases. Reumatologia. 2017;55(5):237-241

3. Esmail S, Knox H, Scott H. Sexuality and the Role of the Rehabilitation Professional. In: JH Stone, M Blouin. International Encyclopedia of Rehabilitation. 2010

4. Esmail S, Darry K, Walter A, Knupp H. Attitudes and perceptions towards disability and sexuality. Disabil Rehabil 2010;32:1148-55

5. Henderson AW, Turner AP et al. Sexual activity after dysvascular lower extremity amputation. Rehabil Psychol. 2016 Aug;61(3):260-8 